\title{
歩行性昆虫のダイナミック歩容解析
}

\section{Dynamic Gait Analysis of Running Single Insect}

\section{学 O古川元揮（九エ大） 学 川尻祐貴（九工大） 正 川原知洋（九工大）}

Motoki FURUKAWA, Yuuki KAWAJIRI, and Tomohiro KAWAHARA

Kyushu Institute of Technology, 2-4 Hibikino, Wakamatsu-ku, Kitakyushu, 808-0196, Japan

Key words: Inkjet Mechanism, High-Speed Vision, Running Insects, Dynamic Stimulation

\section{1. 緒言}

昆虫の行動解析により，生体の運動特性や学習機能を解明しようとする試みが盛んに行われている，その中で も歩行性昆虫は素早く動き回るため, 固定化せずに外部刺激に対する応答特性を調べることが困難であった．そ こで，我々は歩行性昆虫としてクロヤマオオアリ（全長 4 6 mm，移動速度 10 50 mm/s）を選定し，平面上を自 由に走行するアリを経時的に追跡しながら微小液滴で力学刺激を加えることのできるシステムを新たに開発して きた(1)(2). 本発表では, 計測画像データを用いて刺激によるアリのダイナミックな歩容変化を解析する方法につい て議論するとともに，将来的な取り組みについても紹介する.

\section{2. システムの概要及び実験(1)(2)}

開発システムでは, 高倍率で観察を続けながら刺激を行うために, アリを高速ビジョンにより 500 fps で撮影し， 得られたアリの重心位置に対して，XY ステージを制御することでビジョンの視野中心に拡大したアリを捉え続 ける．また，インクジェット機構はピエゾ式のものを用いており，純水を射出することで刺激を行う。

実験では，トラッキングを継続しながらアリが走行しているタイミングでノズルから液滴を射出してその際の アリの挙動を画像として記録した. なお，実験ではノズル先端とアリまでの距離 は, $12 \mathrm{~mm}$ としており, 1 回の 刺激では 100 発の液滴（総量 $1 \mu \mathrm{l}=ア リ の$ 体積の約 $5 \%$ ）を $200 \mathrm{~ms}$ の間に射出した.

\section{3. 解析方法の検討}

実験データの一例を Fig. 1 に示す．今回の解析では，アリの 各部位の刺激前後の相対的な長さ変化に着目して評価した.こ れにより, 瞬間的な刺激によってアリの挙動が大きく変化して いることが確認できた（例えば，足の移動速度が瞬間的に 10 倍向上する).一方で, 刺激を行うことによって足等が腹部の下 に隠れる (オクルージョン) 問題が生じるため, Fig. 1 下部に 示すように足先を線分で結んで凸多角形として近似する方法に ついて検討した。 この場合，他のアリ同士の応答を共通のパラ メータで評価できるようになった.
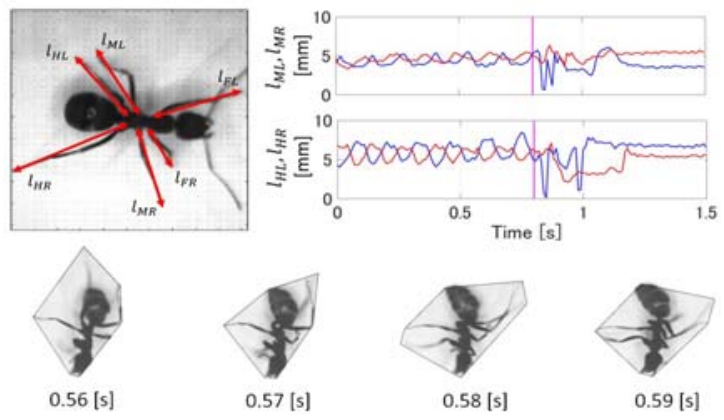

Fig. 1: Examples of the stimulus response of running ant.

\section{4. 結言}

本稿では, 走行性昆虫（アリ）を自由に走行させながら局所刺激を加えることのできるシステム用いて刺激応 答計測を行い，その際の動的な応答を解析する方法について検討を行った．今後は，サンプル数を増やして解析 を行うとともに, 構造的・学的・生物学的な観点からアリの動的な振る舞いについて調查を進める予定である.

\section{文献}

(1) B. Ahmad et al., "Dynamic behavior of running insect activated by high-speed microdroplets manipulation," Int. Conf. on Manipulation, Automation and Robotics at Small Scales (MARSS), paper no. 78, 2018.

(2) 川原ら, “微小液滴を用いた歩行性昆虫のダイナミック刺激応答計測”, 第 31 回バイオエンジニアリング講演会講演 論文集，1D43, 2018. 